\title{
Disposition Effect and Return Predictability in the Tunisian Stock Market
}

\author{
Cheïma Hmida \\ Faculty of Economics and Management of Tunis, \\ University campus Farhat Hached, Tunisia \\ Tel: 2-169-539-4511Ｅ-mail: cheimahmida@gmail.com \\ Ramzi Boussaidi \\ Faculty of Law, Economics and Management of Jendouba, \\ University of Jendouba, Tunisia \\ Tel.: 2-169-872-7019Ｅ-mail: boussaidi.ramzi@yahoo.fr
}

$\begin{array}{lrr}\text { Received: Nov. 22, } 2016 & \text { Accepted: Dec. 2, } 2016 \quad \text { Published: Jan. 3, } 2017 \\ \text { doi:10.5296/ifb.v4i1.10550 } & \text { URL: http://dx.doi.org/10.5296/ifb.v4i1.10550 }\end{array}$

\begin{abstract}
The behavioral finance literature has documented that individual investors tend to sell winning stocks more quickly than losing stocks, a phenomenon known as the disposition effect, and that such a behavior has an impact on stock prices. We examined this effect in the Tunisian stock market using the unrealized capital gains/losses of Grinblatt \& Han (2005) to measure the disposition effect. We find that the Tunisian investors exhibit a disposition effect in the long-run horizon but not in the short and the intermediate horizons. Moreover, the disposition effect predicts a stock price continuation (momentum) for the whole sample. However this impact varies from an industry to another. It predicts a momentum for "manufacturing” but a return reversal for "financial” and "services".
\end{abstract}

Keywords: Disposition effect, Prospect theory, Unrealized capital gain (loss), Behavioral finance 


\section{Introduction}

Traditional finance theory is based on the efficient market hypothesis (EMH) which assumes that investors are rational and that stock prices instantaneously reflect all the available information. As a consequence, prices change in a random way, which makes them unpredictable from historical data. In the 1980s, diverse empirical studies rejected the EMH (Shiller, 1984; Thaler, 1985). A strand of theoretical and empirical literature has emerged to show that some market anomalies are consistent with the presence of investors' irrational trading (e.g., Daniel, Hirshleifer, \& Subrahmanyam, 1998; Barberis, Shleifer, \& Vishny, 1998; and Shiller, 2000). One of the well established regularities in this literature is the disposition effect introduced by Schlarbaum, Lewellen, \& Lease (1978) and, Shefrin \& Statman (1985) defined as the investors' tendency to sell winning stocks too soon and hold on losing stocks too long. Such a behavior is mainly explained by a mixture of the prospect theory of Kahneman \& Tversky (1979) and the mental accounting of Thaler (1980).

To explain how decision makers really behave when confronted with choice under uncertainty, the prospect theory formalizes an S-shaped value function to substitute for the classic expected utility function. Investor's utility is represented as a function of gains and losses measured relative to a fixed reference point, rather than a function of levels of wealth. Such a function is concave in the region of gains and convex in the region of losses indicating that agents are risk-averse in the domain of gains but risk-seeking in the domain of losses. Mental accounting deals, in fact, with that reference point. It indicates how investors establish reference points for the profits generated by individual stocks.

Motivated by the disposition effect as a combination of the prospect theory and mental accounting, Grinblatt \& Han (2005) showed that (i) the spread between the market price of stocks and the reference price increases with past returns and past trading volume and (ii) this spread plays an important role to forecast future returns and explain momentum effect. In this paper we test these two main implications in the Tunisian context using the unrealized capital gains (losses) of Grinblatt \& Han (2005) to proxy for the disposition effect.

The rest of the paper is organized as follows. Section 2 briefly reviews the existing literature. Section 3 presents the research design to examine the determinants of the unrealized capital gains (losses) as a proxy for the disposition effect and its ability to predict returns. Section 4 displays and discusses our empirical results in the Tunisian stock market. Section 5 concludes the paper.

\section{Literature Review}

The disposition effect was initially documented by Schlarbaum et al. (1978) and Shefrin \& Statman (1985) who, through their pioneering work, showed that investors tend to sell winning stocks more quickly than losing stocks. In an early study, Schlarbaum et al. (1978) observed that "individual investors in the aggregate have consistently been net sellers of common stocks”. They collected data of 2506 individual-investor accounts for the period 1964-1970 which they combined with 972 individual investors' questionnaires about investment objectives and decisions. They mainly found that whatever the length of time that 
an investor holds a stock before selling it is (1 month or less; 1 month to 6 months; and 6 months to one year), about $40 \%$ of all capital realizations corresponded to losses. Using the same data and a monthly data on mutual funds shares for the period 1961-1973, Shefrin \& Statman (1985) showed that pattern of losses and gains realizations highlighted by Schlarbaum et al. (1978) are not only due to tax considerations but also to the disposition effect. Odean (1998) analyzed 10000 individual investors' accounts during the period 1987-1993 by distinguishing, for each day, between realized gains or losses and unrealized gains or losses (paper gains or losses). He found that the investors realized $14.8 \%$ of their gains per year, but only $9.8 \%$ of their losses, indicating that they realized their gains $50 \%$ more frequently than they realized their losses. Grinblatt \& Han (2005) considered all the common shares traded on the NYSE and AMEX exchanges during the period July 1962-December 1996. They cross-sectionally regressed weekly stock returns on past returns and average turnover over short, intermediate and long horizons, and the unrealized capital gains (losses) as a proxy for the disposition effect. They found that the aggregate unrealized capital gain has a forecasting ability of future returns better than past returns. Moreover, when this variable is included in the regression, the momentum returns generated for intermediate horizon disappear, indicating that the disposition effect explains the momentum effect. Consistent with the results of Grinblatt \& Han (2005), Frazzini (2006) had documented that the combination between prospect theory and mental accounting helps explain the investor underreaction to news. Using a database on 29000 mutual funds for the period 1980-2003, he showed that the disposition effect induces a return predictability and post-announcement price drift consistent with this phenomenon.

The disposition effect was also documented for professional investors. For example, to evaluate the trading behavior of professional futures traders, Locke \& Mann (2000) associated their performance with the holding period of losers. They found that while all traders hold losers longer than winners, the least successful traders hold losers the longest, and the most successful traders hold losers for the shortest time. Wermers (2003) showed that managers of underperforming funds are reluctant to sell their losing stocks. Kaustia (2010) detected several influences of disposition effect depending on the investor type. He found that household investors are more affected by the disposition effect than professional investors. Further evidence of the disposition effect, was empirically documented in other stock markets such as the Australian stock market (Brown et al., 2002); in Finland (Grinblatt \& Keloharju, 2000), in Japan (Kim \& Nofsinger, 2002) and in French market (Boujelbène et al., 2009). This phenomenon was also detected in real estate markets by, among others, Genesove \& Mayer (2001).

\section{Research Design}

\subsection{Hypotheses}

The main implication of the model of Grinblatt \& Han (2005) is that the unrealized capital gains (losses) used as a measure of the disposition effect has a forecasting ability of future returns. The authors underline that under the hypothesis of investors' heterogeneity, the disposition effect trading makes the reference point (e.g., the cost basis) change across 
investors as well as the aggregate reference point for all the investors. The dynamics of such a process tend to reduce the absolute difference between the market price of a stock and the aggregate reference point, $P_{t}-R P_{t}$, causing a mean reversion of the market price of a stock towards its fundamental value in the subsequent period. In other words, in the region of gains where the reference point lies below the market price; to catch up to the market price the reference point should increase; and hence, generate positive returns. In the region of losses, given that the reference point lies above the market price, it should decrease to adjust to the market price yielding then low past return. Thus, the disposition effect predicts that stocks having paper capital gains will generate higher average returns, while stocks having paper capital losses will suffer lower returns. The adjustment of the reference price to the market price also depends on the trading volume. Indeed, higher trading volume leads to fast convergence of the reference price to the market price.

This analysis was analytically demonstrated by Grinblatt \& Han (2005) as shown by the following equation:

$$
E\left[\frac{P_{t+1}-P_{t}}{P_{t}}\right]=(1-w) V_{t} \frac{P_{t}-R_{t}}{P_{t}}
$$

Where $P_{t}$ denotes the stock price; $V_{t}$, the trading volume; and $w$, a weight. This equation indicates that the expected returns increase with the unrealized capital gains (losses), $\left(P_{t}-R_{t}\right) / P_{t}$, and the trading volume.

Another implication of their model is that the unrealized capital gain/loss is positively correlated with past returns. Stocks with high (low) past returns tend to generate unrealized capital gains (losses).

Based on this analysis, the disposition effect can be stated through the following two hypotheses:

H1: "The unrealized capital gains (losses) tend to increase with past returns and decrease with past trading volume”.

H2: “The disposition effect helps predict stock returns”.

The first hypothesis deals with the determinants of the unrealized capital gains (losses) while the second one deals with the forecasting ability of this variable.

\subsection{The Models}

\subsubsection{Determinants of the Unrealized Capital Gains (losses)}

To check the determinants of the unrealized capital gains (H1), we formally analyze the following two regressions based on the pioneering work of Grinblatt \& Han (2005):

$$
\text { Model 1: } g=a_{0}+a_{1} r_{-1}+a_{2} r_{-12:-1}+a_{3} r_{-36:-13}+a_{4} s
$$


Model 2: $g=a_{0}+a_{1} r_{-1}+a_{2} r_{-12:-1}+a_{3} r_{-36:-13}+a_{4} V_{-1}+a_{5} V_{-12:-1}+a_{6} V_{-36:-13}+a_{7} s$

Where $g$ is used as a proxy for unrealized capital gains (losses); $r_{-t 1:-t 2}$ denotes the lagged cumulative return from month $t-t_{1}$ to $t-t_{2}$; $s$ is the firm size measured as the natural logarithm of market capitalization (stock price times number of shares outstanding) at the end of month $t-1$; $V_{-t 1:-t 2}$ is the average monthly turnover from $t-t_{1}$ to $t-t_{2}$.

The past cumulative returns over short, intermediate, and long horizons are used as control regressors for some well documented return patterns in the literature. The past one-month return is used to control for the short-term reversal effect described by Jegadeesh (1990) as a negative one-month return auto-correlation. Past one year return $r_{-12:-1}$ is used to control for the momentum effect documented by Jegadeesh \& Titman (1993) inducing a short term positive autocorrelation in stock returns. Cumulative return over past twenty four months $r_{-36:-13}$ is intended to control for the reversal effect of De Bondt \& Thaler (1985). The authors have indeed revealed a phenomenon of long-term return reversal leading to a negative return autocorrelation. The trading volume, measured by the turnover, is to control for the possible effect of the trading volume documented, among many, by Lee \& Swaminathan (2000) and Gervais et al. (2001).

The model describes the potential impact of return, volume and size on the market capital gain. We estimate these two models to investigate the determinants of the unrealized capital gains (losses) using two methods: cross-section regression of Fama \& MacBeth (1973) and time series regression.

\subsubsection{Disposition Effect and Return Predictability}

To study the impact of the presence of disposition prone investors on the predictability of stock returns (H2), we consider the following model:

$$
r_{t}=a_{0}+a_{1} r_{-1: 0}+a_{2} r_{-12:-1}+a_{3} r_{-36:-13}+a_{4} \bar{V}+a_{5} s+a_{6} g
$$

The dependent variable in this model is the stock return. The capital gain $g$ is the forecasting variable of interest in the model. We use cumulative past returns for different horizons as control variables for the return patterns described above.

\subsection{Variables Specification}

\subsubsection{Stock Return}

The stock return from $t-1$ to $t$ is computed as follows:

$$
R_{i t}=\frac{P_{i, t}+D_{i, t}-P_{i, t}-1}{P_{i, t-1}}
$$

Where $P_{i t-1}$ and $P_{i t}$ are the closing prices of stock $i$ at $t-1$ and $t$, respectively; and $D_{i t}$, the 
dividend paid between $t-1$ and $t$.

\subsubsection{The Trading Volume}

There are two major measures of trading activity cited in the financial literature: the trading volume and the turnover. The trading volume simply refers to the number of shares traded for each stock. Due to the variation in the number of shares outstanding over time, measuring the activity by the number of shares traded seems inappropriate because it may not reflect the intensification of activity in the market. Lo \& Wang (2000) suggest the turnover as a measure of the trading activity defined as the number of shares traded by the number of shares outstanding.

\subsubsection{Unrealized Capital Gains (losses)}

The impact of the disposition effect on the return predictability is tested through the unrealized capital gains (losses) variable. This measure is the key variable of interest in our empirical analysis because it summarizes the gains and losses experienced by the disposition investors. As a proxy for this variable we use the one suggested by Grinblatt \& Han (2005). As stated by the mental accounting, the unrealized capital gains (losses) require the estimation of a reference price $R P$ for each stock specified as follows:

$$
R P_{t}=\sum_{n=1}^{\infty}\left[V_{t-n} \prod_{\tau=1}^{n-1}\left(1-V_{t-n+\tau}\right)\right] P_{t-n}
$$

Where $P_{t}$ is the price of stock $i$ at time $t$ and $V_{t}$, the turnover at time $t$. The term in parentheses multiplying $P_{t-n}$ is a weight and the sum of all weights should be equal to one. The weight on $P_{t-n}$ refers to the probability that a share was purchased at date $t-n$ and has not been traded since then. The reference price represents, then, a weighted average of past prices where the weights are determined by turnover.

The proxy for the unrealized capital gains (losses) at the beginning of month $t$ is defined as the difference between the Market price and the mean reference point, divided by the market price as follows:

$$
g_{t-1}=\frac{P_{t-2}-R P_{t-1}}{P_{t-2}}
$$

In this formula we use $P_{t-2}$ instead of $P_{t-1}$ as in Grinblatt \& Han (2005) to avoid some microstructure effects such as bid-ask bounce. For past winners, the market price exceeds the reference point and, therefore, the unrealized capital gain is positive. However, for past losers, the unrealized capital gain is negative.

To estimate the aggregate reference price, $R P_{t}$, in a practical way, we use a data of three months. We think that a period of three months is appropriate in our context given that our sample period is shorter relative to the sample period of the authors. 


\subsection{Data and Descriptive Statistics}

From the website of Tunis stock exchange we collect daily closing prices, share trading volume, number of outstanding shares and dividends of 24 Tunisian firms (see appendix 1) for the period that extended from the beginning of January 2003 to the end of December 2013. The choice of such a sample is motivated by the availability and continuity of its data during that period.

Table 1. Descriptive statistics

\begin{tabular}{|l|l|l|l|l|l|l|l|l|}
\hline & Mean & Median & Max & Min & Std. Dev. & Skewness & Kurtosis & Prob (JB) \\
\hline$g$ & 0.9344 & 0.9724 & 0.9900 & 0.6778 & 0.0644 & -1.4585 & 4.4366 & 0.0000 \\
\hline$r_{-1: 0}$ & 0.1495 & 0.0151 & 4.1756 & -0.2896 & 0.6239 & 5.5078 & 34.3153 & 0.0000 \\
\hline$r_{-12:-1}$ & 1.7074 & 0.7556 & 8.8227 & -0.3859 & 2.4866 & 1.7469 & 5.1316 & 0.0000 \\
\hline$r_{-36:-13}$ & 4.8131 & 4.4115 & 15.2449 & -0.1445 & 4.1141 & 0.4382 & 2.0792 & 0.0395 \\
\hline$S$ & 9.8807 & 9.8358 & 11.9941 & 6.6469 & 1.0261 & -0.2532 & 2.9256 & 0.5921 \\
\hline$V_{-1: 0}$ & 0.0402 & 0.0417 & 0.0454 & 0.0004 & 0.0075 & -4.6131 & 22.5098 & 0.0000 \\
\hline$V_{-12:-1}$ & 0.4905 & 0.5000 & 0.9659 & 0.4209 & 0.0549 & 6.8537 & 59.9683 & 0.0000 \\
\hline$V_{-36:-13}$ & 0.9754 & 0.9626 & 1.1581 & 0.9212 & 0.0434 & 1.6810 & 8.7934 & 0.0000 \\
\hline
\end{tabular}

Table 1 reports summary statistics for each variable used in the regressions. As mentioned above the key variable in the model is the unrealized capital gains (losses). Stocks show on average an amount of unrealized gains of 0.9344 reaching a maximum level of 0.9899 in March 2009 and a minimum level of 0,67779 in July 2007. It displays a weak volatility generally similar to that of the turnover but less than the return volatility. We note that the standard deviation of the returns increases with the investment horizon indicating that the long-horizon returns are more volatile than the short horizon returns. Furthermore, the probability of the Jarque-Bera statistic, $\operatorname{Prob}(\mathrm{JB})$, is lower than the conventional levels of significance, except that corresponding to the size, indicating that the distribution of the series differs from the normal distribution. This pattern is usually found in the empirical literature especially for the return distribution.

\section{Empirical Results and Discussion}

\subsection{Determinants of the Unrealized Capital Gains/losses}

As mentioned above, we regress capital gains/losses on the cumulative performance of stock $j$ and the average month turnover for past three periods: the short horizon (defined as the last 
month), the intermediate horizon (between past 1 and 12 months), and the long-term horizon (between 13 and 36 months). The firm size is also included as an explanatory variable. We use the cross section method. Cross sectional regressions which were estimated each month amounted to 96 regressions. The number of regressions decreased because the estimation of variables $r_{-36:-13}$, and $V_{-36:-13}$ requires a delay of 36 months, so the number of months for which we have data for all variables is equal to 132 months minus 36 months.

Table 2 summarizes the estimation results. The cross-section coefficients (column 1 and 2) are the average of the coefficients of the 96 regressions with Student t statistics in parentheses. To investigate the determinants of unrealized capital gains (losses) for stocks over time, we further performed a time series regression (column 3 and 4).

The cross-section regression results indicate that, on average, past returns and firm size explain $76 \%$ of the variation in the unrealized capital gains. When the lagged volume is added (model 2), the three variables explain $40 \%$ of the variation in the unrealized capital gains. There is also a significant positive relation between the unexpected capital gains (losses) and the past one-month and two-year returns in model 1. In model 2 this relation holds only for the past two-year returns. However, for past one-month and one-year returns this relation is sometimes positive, sometimes negative leading, then, to inconclusive and unclear results. These remarks hold also if we adopt a chronological study.

The reliable result corresponds to the long-term horizon returns $\left(r_{-36-13}\right)$. The positive relation found between the unrealized capital gains (losses) and past long horizon return indicate that stocks having high past long-term returns tend to generate positive unrealized gains, while low past return stocks tend to have unrealized capital losses. This finding indicates that the Tunisian disposition investors seem to analyze their investment decisions in long term horizon, unlike, for example, American investors (Grimblat \& Hann, 2005) and French investors (Boujelbène et al., 2009). Indeed, in the U.S market Grinblat \& Hann (2009) find that the positive relation between the unexpected gains (losses) discussed above holds for the three horizons (short, intermediate and long horizon) however it is stronger in intermediate horizon. In the French market, Boujelbène et al. (2009) find similar results except that the effect is stronger in the short horizon.

Furthermore, cross-section regression results indicate a positive relationship between the lagged average turnover and the unrealized capital gains (losses) for short and long-run horizons. In the serial regression, such a relation is detected in short and intermediate horizons. This positive relation means that the unrealized capital gains (losses) increases with the past turnover and consequently the greater the trading volume is, the slower the reference price converges to the market price. Such a relation is inconsistent with the prediction of the model of Grinblatt \& Han (2005) where the unrealized capital gains (losses) should be negatively correlated with past trading volume. In fact, an increase in trading volume should narrow the spread between the reference price, RP, and the market price, P; which means that high trading volume makes the reference price converges faster to the market price. This is not the case in our investigation. Unlike U.S investors (Grinblatt \& Han, 2015) and French investors (Boujelbène et al., 2009), Tunisian investors seem to make the reference price 
adjust slowly to the market price despite their trading activity. We think that this is due to the fact that the trading volume in the Tunisian stock market is not high enough to make the reference point catch up to the market price. Compared to these markets, the Tunisian market is still a small emerging market where trading volume is relatively low.

Table 2. Determinants of unrealized capital gain (loss)

\begin{tabular}{|l|l|l|l|l|}
\hline & \multicolumn{2}{|l|}{ Fama and MacBeth regression } & \multicolumn{2}{l|}{ Chronological study } \\
\hline \multirow{2}{*}{$a_{0}$} & $\begin{array}{l}-11.8966^{* *} \\
(-2.401)\end{array}$ & $\begin{array}{l}-0.9727^{* * *} \\
(-55.08)\end{array}$ & $\begin{array}{l}0.6610^{* * *} \\
(6.174)\end{array}$ & $\begin{array}{l}1.1877^{* * *} \\
(29.69)\end{array}$ \\
\hline$r_{-1: 0}$ & $\begin{array}{l}1.0050^{* * *} \\
(17.09)\end{array}$ & $\begin{array}{l}-0.3095^{* * *} \\
(-12.67)\end{array}$ & $\begin{array}{l}-6.5585^{*} \\
(-2.138)\end{array}$ & $\begin{array}{c}0.0006 \\
(0.081)\end{array}$ \\
\hline$r_{-12:-1}$ & $-0.4463^{* * *}$ & $0.0096^{* * *}$ & $0.4925^{*}$ & -0.0001 \\
$(-3.825)$ & $(4.613)$ & $(2.006)$ & $(-0.150)$ \\
\hline \multirow{2}{*}{$r_{-36:-13}$} & $0.0272^{*}$ & $0.0083^{* * *}$ & $0.0411^{*}$ & $10.6584^{* * *}$ \\
\hline$S$ & $(1.653)$ & $(7.891)$ & $(1.979)$ & $(26.70)$ \\
\hline$V_{-1: 0}$ & $1.2812^{* *}$ & $0.1327^{* * *}$ & $0.0218^{* *}$ & $-0.0248^{* * *}$ \\
\hline$V_{-12:-1}$ & $(2.501)$ & $(16.76)$ & $(2.014)$ & $(-7.921)$ \\
\hline$V_{-36:-13}$ & & $6.6033^{* * *}$ & & 0.0097 \\
& & $(4.179)$ & & $(1.207)$ \\
\hline Adj $R^{2}$ & & -0.2649 & & $0.9229^{* * *}$ \\
& & $(-0.843)$ & & $(35.71)$ \\
\hline
\end{tabular}

Note. $* * *, * *$ and $*$ denote statistical significance at the $1 \%, 5 \%$ and $10 \%$ levels, respectively.

Note also that the firm size affects positively the unrealized capital gain except in the second model based on the chronological study. This indicates that big firms generally tend to generate high capital gains.

We further explore the determinants of the unrealized capital gains (losses) for three industries composing our sample in an attempt to explain the above results. We only present the cross-section estimation results of model 1 in table 3 given that this model offered higher explanation power of the variation of the unrealized capital gains (losses) than model 2. Similar results, available on request, were obtained with model 2.

The main finding highlighted based on this table is that the past two-year return coefficients $\left(r_{-36-13}\right)$ are significantly positive for the services and manufacturing industries, while it is not the case for the financial industry. We can deduce that the robust long term disposition effect found above for the whole sample comes from the services and manufacturing industries. One possible explanation for this is that the finance sector is mainly composed of banks and 
dominated by institutional investors who are less affected by the disposition effect. Adding to that, the Tunisian state, through the central bank, pays a particular attention to the financial sector, which makes it well protected against such a behavioral bias.

For short horizon, only the services industry displays a significantly positive relation between the past returns and unrealized gains inconsistently with the disposition effect hypothesis. This effect is largely stronger than that for long horizon. For the intermediate horizon this effect exists only in the manufacturing industries. Furthermore, the positive relationship between firm size and unrealized gains (losses) found above for the whole sample still holds for the three industries.

Table 3. Determinants of capital gains (losses) in the three industries

\begin{tabular}{|l|l|l|l|}
\hline & Financial & Services & Manufacturing \\
\hline$a_{0}$ & $0.8437^{* * *}$ & $0.6374^{* * *}$ & $0.4237^{* * *}$ \\
& $(24.51)$ & $(11.34)$ & $(8.141)$ \\
\hline$r_{-1: 0}$ & 0.0208 & $0.4625^{* * *}$ & -0.0131 \\
& $(1.626)$ & $(5.842)$ & $(-0.376)$ \\
\hline$r_{-12:-1}$ & $-0.0151^{*}$ & $-0.0419^{* * *}$ & $0.0367^{* * *}$ \\
\hline \multirow{2}{*}{$r_{-36:-13}$} & $(-1.994)$ & $(-5.237)$ & $(3.637)$ \\
\hline \multirow{2}{*}{$S$} & $-0.0046^{* * *}$ & $0.0089^{* * *}$ & $0.0105^{*}$ \\
& $(-4.656)$ & $(7.011)$ & $(1.914)$ \\
\hline Adj $R^{2}$ & $0.0141^{* * *}$ & $0.0196^{* * *}$ & $0.0494^{* * *}$ \\
\hline
\end{tabular}

Note. ***, ** and * denote statistical significance at the $1 \%, 5 \%$ and $10 \%$ levels, respectively.

\subsection{Disposition Effect and Return Predictability}

Table 4 displays the results of the cross sectional estimated regressions performed every month for our entire sample and the three industries composing it. The past-one month return coefficient is significantly positive indicating a positive one-month return autocorrelation not consistent with the short-term reversal effect. It is rather consistent with the momentum effect. However, the coefficients corresponding to past one-year and two-year returns are negative and significantly different from zero indicating intermediate and long-term return reversal consistent with the overreaction phenomenon documented by De Bond \& Thaler (1985) in the US stock market. The long term reversal (for 2 years) finding seems to be robust since it holds for the three industries. This is consistent with the findings of Boussaidi (2015) in the Tunisian stock market who found that such a reversal seems to be explained by a multidimensional risk including the market risk, the firms' size and the book to market, in addition to the overconfidence bias. However, for one year horizon, only the manufacturing industry displays a return reversal, while the financial and services industries displays a 
momentum effect. For one-month horizon, the momentum effect found for the whole sample seems to come from the financial and manufacturing industries which display significantly positive return autocorrelation. In one word, these results indicate an evidence of return predictability by past return in the Tunisian stock market.

In addition, the significantly negative sign of the coefficient corresponding to the market capitalization indicates the existence of the size effect in the Tunisian stock market during our sample period for the whole sample as well as for the three industries. Such an effect indicates a negative relationship between the firm size and the current stock returns in line with the findings of Banz (1981) and Grinblatt \& Han (2005).

We also find a significantly positive correlation between lagged trading volume and current stock returns. This means that higher (lower) trading volume predicts higher (lower) stock returns.

Finally and most important of all, our results show a positive relationship between the monthly returns and the unrealized capital gain for the whole sample. This indicates that the disposition effect positively influences stock returns. In other words, a variation in unrealized capital gains (losses) predicts a variation in the same sense in stock prices, consistently with the momentum effect. Such an influence holds only for the manufacturing industry where all the exogenous variables explain $60 \%$ of the variation in stock returns.

Table 4. Expected returns, past returns capital gains (losses)

\begin{tabular}{|c|c|c|c|c|}
\hline & Whole sample & Financial & Services & Manufacturing \\
\hline$a_{0}$ & $\begin{array}{l}0.3098^{* * *} \\
(8.304)\end{array}$ & $\begin{array}{l}8.5464^{* * *} \\
(12.42)\end{array}$ & $\begin{array}{l}-6.3897 * * * \\
(-17.49)\end{array}$ & \begin{tabular}{|l}
$-0.2835 * * *$ \\
$(-20.11)$ \\
\end{tabular} \\
\hline$r_{-1: 0}$ & $\begin{array}{l}1.1504^{* * *} \\
(61.94)\end{array}$ & $\begin{array}{l}0.1526^{*} \\
(1.752)\end{array}$ & $\begin{array}{l}-0.0081 \\
(-0.054) \\
\end{array}$ & $\begin{array}{l}2.6198 * * * \\
(43.23) \\
\end{array}$ \\
\hline$r_{-12:-1}$ & $\begin{array}{l}-0.0127 * * * \\
(-6.522)\end{array}$ & $\begin{array}{l}0.0501^{* * *} \\
(17.99)\end{array}$ & $\begin{array}{l}0.0436 * * * \\
(9.937)\end{array}$ & $\begin{array}{l}-0.0567 * * * \\
(-13.82)\end{array}$ \\
\hline$r_{-36:-13}$ & $\begin{array}{c}-0.001^{* * *} \\
(-12.28) \\
\end{array}$ & $\begin{array}{l}-0.0368 * * * \\
(-12.38)\end{array}$ & $\begin{array}{l}-0.0235^{* * *} \\
(-53.06) \\
\end{array}$ & \begin{tabular}{|l|}
$-0.0442 * * *$ \\
$(-28.71)$ \\
\end{tabular} \\
\hline$S$ & $\begin{array}{l}-0.0005^{* * *} \\
(-3.545)\end{array}$ & $\begin{array}{l}-8.0271^{* * *} \\
(-7.131)\end{array}$ & $\begin{array}{l}-5.9220 * * * \\
(-1.716)\end{array}$ & $\begin{array}{l}-5.7832 * * * \\
(-19.81)\end{array}$ \\
\hline $\bar{V}$ & $\begin{array}{l}12.015^{* * * *} \\
(8.604)\end{array}$ & $\begin{array}{l}0.0738^{* * *} \\
(5.601)\end{array}$ & $\begin{array}{l}0.8743^{*} \\
(9.503)\end{array}$ & $\begin{array}{l}0.0387^{* * *} \\
(4.084)\end{array}$ \\
\hline$g$ & $\begin{array}{l}0.1785^{* * *} \\
(8.936)\end{array}$ & $\begin{array}{l}-9.2045^{* * *} \\
(-12.41)\end{array}$ & $\begin{array}{l}-1.7740 * * * \\
(-4.068) \\
\end{array}$ & \begin{tabular}{|l}
$0.2216^{*}$ \\
$(1.799)$ \\
\end{tabular} \\
\hline $\operatorname{Adj} R^{2}$ & 0.4777 & 0.4412 & 0.0635 & 0.6055 \\
\hline
\end{tabular}

Note. ${ }^{* * *}, * *$ and * denote Statistical significance at the $1 \%, 5 \%$ and $10 \%$ levels, respectively. 


\section{Conclusion}

The disposition effect is an individual behavior meaning the tendency of investors to sell winning stock the sooner and to hold losers the longer. This effect results from the combination of the prospect theory and the mental accounting. We examined this anomaly in the Tunisian stock market in order to check the impact of the presence of disposition investors on stock prices. We first studied the determinants of this effect proxied by the unrealized capital gains (losses). We found that long-run past returns affect positively the unrealized capital gains (losses) while it's not the case for short and intermediate horizons. Moreover, the disposition effect seems to predict a momentum effect for the whole sample but its impact differs from an industry to another. For manufacturing it still predicts a stock price continuation, while for financial and services, it predicts a return reversal.

\section{Acknowledgement}

The authors would like to thank Professor Mohamed Chaker Chafai and the anonymous referees for their helpful comments and suggestions.

\section{References}

Banz, R. W. (1981). The relationship between return and market value of common stocks. Journal of Financial Economics, 9, 3-18. https://doi.org/10.1016/0304-405X(81)90018-0

Barberis, N., Shleifer, A., \& Vishny R., (1998). A model of investor sentiment. Journal of Financial Economics, 49, 307-343. https://doi.org/10.1016/S0304-405X(98)00027-0

Boujelbène, M. A, Boujelbène, M., \& Bouri, A. (2009). Disposition effect and momentum: prospect theory and mental accounting framework. Journal of Behavioral Finance, 60, 1-34.

Boussaidi, R. (2015). An empirical essay to explain the contrarian profits in the Tunisian stock market: Behavioral approach vs. rational approach. International Journal of Economics and Finance, 7, 11-28. https://doi.org/10.5539/ijef.v7n12p11

Brown, P., Chappel, N., Da Silva, R. R., \& Walter, T. (2002). The Reach of the Disposition Effect: Large Sample Evidence across Investor Classes. European Finance Association Conference, Berlin. https://doi.org/10.2139/ssrn.302655

Daniel, K., Hirshleifer, D., \& Subrahmanyam, A. (1998). Investor psychology and security market under and overreactions. Journal of Finance, 53, 1839-1885. https://doi.org/10.1111/0022-1082.00077

De Bondt, W. F. M., \& Thaler, R. (1985). Does The Stock Market Overreact? Journal of Finance, 40, 793-805. https://doi.org/10.1111/j.1540-6261.1985.tb05004.x

Fama, E., \& MacBeth, J. (1973). Risk, return, and equilibrium: Empirical tests. Journal of Political Economy, 81, 607-636. https://doi.org/10.1086/260061

Frazzini, A. (2006). The Disposition Effect and Underreaction to News. Journal of Finance, 4, 2017-2046. https://doi.org/10.1111/j.1540-6261.2006.00896.x 
Genesove, D., \& Mayer, C. (2001). Loss Aversion and Seller Behavior: Evidence from the Housing Market the Quarterly. Journal of Economics, 116, 1233-1260. https://doi.org/10.3386/w8143

Gervais, S., Kaniel, R., \& Mingelgrin D. H. (2001). The Hight-Volume Return Premium. Journal of Finance, 56(3), 877-919. https://doi.org/10.1111/0022-1082.00349

Grinblatt, M., \& Han, B. (2005). Prospect theory, mental accounting, and momentum. Journal of Financial Economics, 78, 311-339. https://doi.org/10.1016/j.jfineco.2004.10.006

Grinblatt, M., \& Keloharju, M. (2000). The Investment Behavior and Performance of Various Investor-Types: A Study of Finland's Unique Data Set. Journal of Financial Economics, 55, 43-67. https://doi.org/10.1016/S0304-405X(99)00044-6

Jegadeesh, N. (1990). Evidence of Predictable Behavior of Security Returns. Journal of Finance, 45, 88-898. https://doi.org/10.1111/j.1540-6261.1990.tb05110.x

Jegadeesh, N., \& Titman, S. (1993). Returns to Buying Winners and Selling Losers: Implication for Stock Market Efficiency. Journal of Finance, 48, 65-91. https://doi.org/10.1111/j.1540-6261.1993.tb04702.x

Kahneman, D., \& Tversky, A. (1979). Prospect theory: An Analysis of Decision under Risk. Econometrica, 47, 263-291. https://doi.org/10.2307/1914185

Kahneman, D., \& Lovallo, D. (1993). Timid choices and hold forecasts: a cognitive perspective on risk taking. Management Science, 39, 17-31. https://doi.org/10.1287/mnsc.39.1.17

Kim, K. A., \& Nofsinger, J. R. (2003). The behavior and performance of individual investors in Japan. Pacific-Basin Finance Journal, 11, 1-22.

Kaustia, M. (2010). Disposition effect, Chapter 10 in Behavioral Finance. (Robert W. Kolb Series in Finance), In H. K. Baker, J. R. Nofsinger, (Eds.). Hoboken, New Jersey: John Wiley \& Sons, Inc. https://doi.org/10.1002/9781118258415.ch10

Lee, C. M. C., \& Swaminathan, B. (2000). Price Momentum and Trading Volume. Journal of Finance, 55, 2017-2069. https://doi.org/10.1111/0022-1082.00280

Lo, A. W., \& Wang, J. (2000). Trading Volume: Definitions Data Analysis, and Implications of Portfolio Theory. Review of Financial Studies, 13, 257-300. https://doi.org/10.1093/rfs/13.2.257

Odean, T. (1998). Are Investors Reluctant to Realize Their Losses? Journal of Finance, 53, 1775-1798. https://doi.org/10.1111/0022-1082.00072

Schlarbaum, G. G., Lewellen, W. G., \& Lease, R. C. (1978). Realized Returns on Common Stock Investments: The experience of individual investors. Journal of Business, 51, 299-325. https://doi.org/10.1086/295998

Shiller, R. J. (1984). Stock Prices and Social Dynamics. Brookings Papers on Economic 
Activity, 2, 457-498. https://doi.org/10.2307/2534436

Shiller, R. J. (2000). Irrational exuberance. Princeton, New Jersey: Princeton University Press.

Shefrin, H., \& Statman, M. (1985). The Disposition to Sell Winners Too Early and Ride Losses Too Long:Theory and Evidence. Journal of Finance, 40, 777-790. https://doi.org/10.1111/j.1540-6261.1985.tb05002.x

Thaler, R. H. (1985). Mental accounting and consumer choice. Marketing Science, 4, 199-214. https://doi.org/10.1287/mksc.4.3.199

Thaler, R. (1980). Toward a positive theory of consumer choice. Journal of Economic Behavior and Organization, 1, 39-60. https://doi.org/10.1016/0167-2681(80)90051-7

Wermers, R. (2003). Is money really "smart?" New evidence on the relation between mutual fund flows, manager behavior, and performance persistence. Working paper, University of Maryland.

\section{Appendix}

Firms composing our sample during the period 2006-2013:

\begin{tabular}{lll}
\hline 1 & ADWYA & Société Adwya \\
2 & ARTES & Automobile Réseau Tunisien Et Services \\
3 & ASSAD & Société L'accumulateur Tunisien \\
4 & ATL & Arab Tunisian Lease \\
5 & TJARI & Banque Attijari De Tunisie \\
6 & BH & Banque De L’habitat \\
7 & BIAT & Banque Internationale Arabe De Tunisie \\
8 & BNA & Banque Nationale Agricole \\
9 & BT & Banque De Tunisie \\
10 & BTE & Banque De Tunisie Et Des Emirats (Adp) \\
11 & WIFAK & El Wifack Leasing \\
12 & LSTR & Electrostar \\
13 & MNP & Société Nouvelle Maison De La Ville De Tunis \\
14 & SFBT & Société Frigorifique Et Brasserie De Tunis \\
15 & SIAME & Société Industrielle d'appareillage et de Matériels Electriques \\
16 & SIPHA & Société Des Industries Pharmaceutiques De Tunisie \\
17 & SITS & Société Immobilière Tuniso-Saoudienne \\
18 & SOTET & Société Tunisienne D'entreprises De Télécommunications \\
19 & STPIL & Société De Transport Des Hydrocarbures Par Pipelines \\
20 & TPR & Société Tunisie Profiles Aluminium \\
21 & TLS & Tunisie Leasing \\
22 & STB & Société Tunisienne De Banque \\
23 & UIB & Union Internationale De Banques \\
24 & SPDIT & Ste De Place. Et De Develop. Indus. Et Touris.-SICAF \\
\hline
\end{tabular}




\section{Copyright Disclaimer}

Copyright for this article is retained by the author(s), with first publication rights granted to the journal.

This is an open-access article distributed under the terms and conditions of the Creative Commons Attribution license (http://creativecommons.org/licenses/by/3.0/). 